\title{
Effects of Xiantao sewage treatment on microbial community structure of shallow groundwater in wetland
}

Shu-Fen Song ${ }^{1}$ Xiu-Fang Gao ${ }^{2 *}$ Fan Yang $^{3}$

${ }^{1}$ (College of Life Science, Yangtze University, Jingzhou, Hubei 434025, China)

${ }^{2 *}$ (College of resources and Environment, Yangtze University, Wuhan, Hubei 430000, China)

${ }^{3}$ (Wuhan Yihui far Biotechnology Co. Ltd, Wuhan, Hubei 430000, China)

Address :Yangtze University, Wuhan, Hubei, China

(Tel) : +86-13212719979

(Fax) : +86-0716-8066257

(E-mail) : gxf2017@yangtzeu.edu.cn

\section{Abstract}

In order to solve the problem of urban domestic sewage treated by semi natural wetland method with high connectivity between surface water and underground water in the flood diversion channel, Whether there is a blank study on the pollution of shallow groundwater. The community structure and abundances of $\mathrm{COD}_{\mathrm{Cr}}$, total nitrogen, total phosphorus and microorganism were added to the surface water. Environmental factors such as $\mathrm{COD}_{\mathrm{Cr}}, \mathrm{TN}, \mathrm{TP}, \mathrm{NH}_{4}{ }^{+}-\mathrm{N}$ and microbial community and abundance indices were monitored through surface water and groundwater. In this study, physical and chemical indicators, microbial diversity and community structure 
of 12 water samples from Xiantao artificial wetland were studied by using the Illumina Miseq sequencing technique and the resulting microbial data were statistically analyzed in combination with environmental variables. The results showed that $\mathrm{COD}_{\mathrm{Cr}}$ concentration had a very significant positive correlation with total microbial communities $(\mathrm{r}=0.530, \mathrm{P}<0.01), \mathrm{NH}_{4}{ }^{+}-\mathrm{N}$ and $\mathrm{TN}$ were significantly positively correlated $(\mathrm{r}=0.337$ and $0.325, \mathrm{P}<0.05)$. In addition, $\mathrm{COD}_{\mathrm{Cr}}$ concentration was highly positively correlated with abundant groups $(\mathrm{r}=0.520, \mathrm{P}<0.05), \mathrm{NH}_{4}{ }^{+}-\mathrm{N}$ and TN were significantly positively correlated $(r=0.325$ and $0.304, \mathrm{P}<0.05)$. For rare taxa, they might be more sensitive to the environment than their abundant groups. The relative abundance of the rare group is 0 at the depth of $10 \mathrm{~m}$, so we should carefully evaluate microbial reaction (rare group) environmental conditions in the future.

Key world: Wetland method, shallow groundwater, microorganism, diversity

\section{Introduce}

In recent years, the crisis in China's groundwater has been highly concerned by the international community.In July 15, 2010, the News edition of the Nature ${ }^{1}$ magazine covered the whole page of the groundwater crisis in China (Qiu, 2010). In some areas, the storage of groundwater is decreasing at an alarming rate, and $90 \%$ of the water in the country has been polluted in varying degrees, of which $60 \%$ are seriously polluted.

According to the survey, in addition to landfill and gas station, urban sewage, industrial wastewater and agricultural wastewater from some large farms are also polluting in China's urban groundwater ( $\mathrm{Xu}, 2012)$. Some industrial and mining enterprises and large farms, driven by economic benefits, try to drain the sewage into the underground and think that the polluted water is "safe".In fact, shallow 
groundwater and deep groundwater are only a relative concept, the distribution of groundwater is not uniform, and the absolute aquifers are not.The shallow groundwater and deep water are interconnected in many places, so the shallow groundwater will naturally flow into the deep layer.

Artificial wetland is an ecological wastewater treatment technology a new type of environmental protection (Yin, 2007), It has been successfully applied to storm flood, domestic sewage and eutrophication water purification (Kobayashi, et al., 2009; Iasur-Kruh, et al., 2010; Peralta, et al., 2012; Sánchez-Carrillo, et al., 2014).

The first example is to use the unused spillway semi natural wetland for urban sewage treatment, and the Xiantao wetland wastewater treatment plant system is made using the high water level surface water and the high connectivity water system of the groundwater. There are few studies on the influence of sewage treatment on groundwater by artificial wetland. The community and abundance of microbes in shallow groundwater under this condition, especially the effect of the cumulative results of pollutants on the groundwater under the long-term treatment conditions is almost not. The comprehensive study on the utilization of unused spillways, the treatment of domestic sewage by semi natural wetland, wetland method, the community and abundance of microbes in groundwater, the contamination of groundwater, the community and abundance of microbes in groundwater and the environmental factors of groundwater are the blank. The microbial diversity of surface water is one of the most important branches of water environment $(\mathrm{Fu}$, et al., 2017; Guo, 2010).The physical and chemical properties of surface water vary with the conditions of space and light. However, the distribution of microorganisms in shallow groundwater under different depths is also a very important research topic. In this 
study, the samples not only have a wide range of samples, but also select three depths of $0.2 \mathrm{~m}, 5 \mathrm{M}$ and $10 \mathrm{~m}$ in the vertical direction. The community structure and abundance index of $\mathrm{COD}_{\mathrm{Cr}}$, total nitrogen, total phosphorus and microbes are added to the surface water, and the environmental factors of surface water and groundwater (such as $\mathrm{COD}_{\mathrm{Cr}}, \mathrm{TN}, \mathrm{TP}, \mathrm{NH}_{4}{ }^{+}-\mathrm{N}$ ) and high throughput sequencing are monitored. Methods the microbial diversity was analyzed, and the structure and composition of microbial community in the shallow groundwater of domestic sewage, the relationship between the microbial community and the environmental factors were carried out by the wetland method. It can reflect the influence of the microbial community in the shallow groundwater during the operation of the wetland, and the correlation between the microbial community and the abundance change and the pollution level of the organic matter in the groundwater can provide the follow-up workers with the corresponding theoretical and practical support.

\section{Materials and Methods}

\subsection{Introduction of Xiantao wetland method for domestic sewage treatment test}

The Xiantao wetland experimental base is introduced in detail and the sampling azimuth reference Song (Song et al., 2015).

\subsection{Determination of sampling and environmental factors of water samples}

Methods of sampling and environmental factor determination refer to Song (Song et al., 2015).

\subsection{Sequencing analyses}

The processing method of raw data is obtained by referring to Song (Song et al., 2015). 


\section{Results}

\subsection{Analysis of physical and chemical indexes of wastewater.}

According to the state regulations, the treated sewage should reach the standard of pollutant discharge of GB 18918-2002 «municipal wastewater treatment plant», $\mathrm{M} 1(400 \mathrm{~m})$ and $\mathrm{M} 4(600 \mathrm{~m})$ were high concentration(COD $\left.\mathrm{Cr}_{\mathrm{r}}>120 \mathrm{mg} / \mathrm{L}\right) ; \mathrm{M} 7(3000 \mathrm{~m})$ had achieved the two level standard of «municipal wastewater treatment plant»(100 $\mathrm{mg} / \mathrm{L}<\mathrm{COD}_{\mathrm{Cr}}<120 \mathrm{mg} / \mathrm{L}$ ); and M2, M3, M5, M6, M8 and M9 were reach the first level standard $\left(\mathrm{COD}_{\mathrm{Cr}}<50 \mathrm{~g} / \mathrm{L}\right)$. The $\mathrm{TP}$ of these samples were $0.02-5.14 \mathrm{mg} / \mathrm{L}$, very significant positive correlation with $\mathrm{COD}_{\mathrm{Cr}}(\mathrm{r}=0.984, P<0.0001)$. Samples $\mathrm{NH}_{4}{ }^{+} \mathrm{N}$ contents were $0.49-8.81 \mathrm{mg} / \mathrm{L}$, very significant positive correlation with $\mathrm{COD}_{\mathrm{Cr}}(\mathrm{r}$ $=0.987, P<0.0001)$. Samples TN contents were $1.13-19.17 \mathrm{mg} / \mathrm{L}$, very significant positive correlation with $\operatorname{COD}_{\mathrm{Cr}}(\mathrm{r}=0.983, P<0.0001)$ (Table 1). As can be seen from table 1, along with the level of wetland before treatment, the environmental factors gradually decreased. There is no phosphorus in the groundwater quality standard (GB/T 14848-2017). It is generally believed that the concentration of phosphorus in the groundwater is very low, but the phosphorus in the groundwater is present, and the amount of the phosphorus is large, and the pollution of phosphorus can not be ignored. The characteristics of the highly connected water system of surface water and groundwater are fully reflected here. From the surface water to the vertical direction of groundwater, that is, from surface water, groundwater depth of 5 meters, and buried depth of 10 meters, the environmental factors index is also gradually decreasing.

But from the horizontal direction of the wetland in the depth of 5 meters and 10 meters, the reduction is different.

\subsection{Microbial diversity of the researched constructed wetland}


A total of 80524 high-quality sequences with $5755-24785$ sequences (mean=13454) and 726.9-1077.1 OTUs (mean=855) for twelve water samples were obtained. the diversity index, including Shannon (4.9-6.0), phylogenetic distance of a whole tree(48.1-68.5), and Chao 1 (2243.8-3291.9). All the calculated diversity indices in this study decreased with geographical position variation of azimuth of the studied samples (Table 2). The dominant phyla (the relative abundance of more than 1\%) in the studied samples were Proteobacteria, Bacteroidetes, Actinobacteria, Cyanobacteria, Verrucomicrobia, Firmicutes, Acidobacteria, Chloroflex and Euryarchaeota (Figure 1). Proteobacteria is the most abundant phylum (more than $84 \%$ of total sequence reads).

Among the retrieved OTUs, a total of 8-20 OTUs were classified as abundant OTUs. These abundant OTUs accounted for 5.63-15.15\% of total OTUs and represented $64.66-80.85 \%$ relative abundance of sequence reads in the studied samples. In contrast, a total of 0-139 rare species were identified and they accounted for $0-64.19 \%$ of total OTUs and $0-6.98 \%$ relative abundance of sequence reads in the studied samples (Table 3). Most abundant OTUs belonged to Proteobacteria and Bacteroidetes, which the abundant OTUs accounted for $29.61-72.66 \%$ and $0-38.5 \%$ of total sequence reads in the studied samples (Table 4).

The studied shows that the water samples with similar physical and chemical tests have similar patterns of microbial structure. For example, cluster analysis revealed that the 12 samples are aggregated into two large clusters, of which the wetland surface water samples (M1, M4 and M7) are clustered into one cluster. The 5m deep and 10m deep water samples are divided into one cluster (except M9) (Figure 2). The horizonta direction Surface water of groundwater in Constructed Wetlands (MC1, M1, M4 and M7) were dominated by sequences affiliated with Betaproteobacteria, 
Gammaproteobacteria, Epsilonproteobacteria, Actinobacteria. The depth is 5 meters (MC2, M2, M5, and M8) were dominated by sequences affiliated with Betaproteobacteria, Gammaproteobacteria, Bacteroidia, Melainabacteria, Sphingobacteriia. The depth is 10 meters (MC3, M3, M6 and M9) were dominated by Betaproteobacteria, Bacilli, Gammaproteobacteria, Alphaproteobacteria, Flavobacteriia, Sphingobacteriia. the vertical of 400m (M1, M2 and M3) were dominated by sequences affiliated with Betaproteobacteria. 600m (M4, M5 and M6) were dominated by sequences affiliated with Betaproteobacteria, Bacilli, Gammaproteobacteria, Alphaproteobacteria, Sphingobacteriia. 3000m(M7, M8 and M9)were dominated by sequences affiliated with Betaproteobacteria, Gammaproteobacteria, Flavobacteriia, Epsilonproteobacteria, Melainabacteria, Sphingobacteriia. The contrast samples(MC1, MC2 and MC3) were dominated by Betaproteobacteria, Gammaproteobacteria, Bacteroidia, Actinobacteria (Table 5).

\subsection{Statistical analyses.}

Statistical analyses further corroborated the influence of different positions on the structure of community in the studied samples. Mantel test showed that structure of community of the treatment of surface water from domestic sewage by wetland method was correlated $(P<0.01)$ with $\mathrm{COD}_{\mathrm{cr}}(\mathrm{r}=0.520)$ (Table 6). Furthermore, Bray-Curtis similarity of abundant microbial communities were significantly correlated $(\mathrm{r}=0.530)$ with treatment of surface water from domestic sewage by wetland method (Figure 3). Likewise, Mantel test indicated that the abundant structure of community were great significantly correlated to $\mathrm{COD}_{\mathrm{cr}}(\mathrm{r}=0.530)($ Table 6). In addition, Mantel tests also showed that three other indicators the total and abundant structure of community were significantly correlated with $\mathrm{NH}_{4}{ }^{+}-\mathrm{N}(\mathrm{r}=0.325$ 
and $\mathrm{r}=0.337), \mathrm{TN}(\mathrm{r}=0.304$ and $\mathrm{r}=0.325)$ (Table 6).

167

\section{Discussion}

The interaction of surface and groundwater covering almost in the process of water circulation, rainfall (Vidal, et al., 2008), interception (Schellekens, 2000), evaporation (Zhang, et al., 2008), infiltration (Yimer, et al., 2008), mathematical simulation and physical processes, and filtration (Fukada, et al., 2008), pollutants migration (Willhelm, et al., 1996) and other chemical processes, biological processes and the main contents of the study appear in the review article or some aspects of bioremediation for pollution.

In constructed wetlands, the removal of pollutants is mainly done through the physical, chemical and biological synergies of the matrix, microbes and plants in the wetland (Babatunde, et al., 2008). It is generally believed that biological action is the core factor of sewage purification in artificial wetland (Liang, et al., 2003). Some scholars through soil column simulation test, the effect of underground infiltration system on pollutant removal in sewage has been studied (Lance, et al., 1980). The results also confirm that the main removal effect in underground percolation system is biological action.

Combined with artificial wetland, the changes of microbial community in shallow groundwater in artificial wetland in the process of habitat restoration were compared and analyzed. It is found that geographical location is an important factor affecting the microbial diversity and community structure of the lake surface sediments. This finding is consistent with recent studies. Some scholars found that the number of microbes in fine sand decreased with the increase of sand depth (Liu, 2014). Some scholars found that the number of bacteria and fungi on the surface of the system was 
significantly higher than that of the lower layer. As the vertical height of the system deepened, the number of fungi decreased gradually (Zhou, et al., 2009). The total trend of bacteria and nitrite in the vertical direction is decreasing, and the number of microbes in the upper layer is more than that in the lower layer. The overall trend of bacteria and nitrite in the direction of water flow is also decreasing, that is, the front part is more than the middle and posterior parts (Fu, et al., 2005). Some scholars pointed out that in the same vertical subsurface flow wetland system, planting different plants also had an impact on the microbial community in the wetland, but they only had a significant impact on the $0 \sim 10 \mathrm{~cm}$ surface of the system, and the deeper microbial communities were basically similar (Sleytr, et al., 2009). In addition, in this study, experiments showed that the total microbial community structure was also significantly related to the $\mathrm{NH}_{4}{ }^{+}-\mathrm{N}$ and $\mathrm{TN}$ values of wetland, but lower than the correlation coefficient of $\mathrm{COD}_{\mathrm{cr}}(\mathrm{r}=0.337,0.325 \mathrm{VS} \mathrm{R}=0.530$, Table 6).

It is noteworthy that M9 and wetland surface water samples (M1, M4, M7), M6 and M8, M2, M3 and M5 three groups of samples gathered separately (Figure 2), indicating that some similar microorganisms may be shared between polluted area and water purification area. The reason for this phenomenon is that the concentration of pollutants in the surface water samples is too high to show the eutrophication state. Therefore, the number of microbes is large, and the concentration of pollutants decreases with the depth and direction of flow, and the nutrients are less, so the number of microbes is less.

It is also notable that the relative abundance of rare and abundant species of high surface water in the surface water treated in this study is less than that in the target area (Table 3 and 4), The rare communities showed more obvious reaction than the rich communities (which were proved by larger relative abundance), which indicated 
that rare taxa might have more restrictive distribution than the rich groups. Abundant groups can make use of abundant resources, thus having a very low probability of extinction and high probability of propagation. In addition, rare taxa may have less suitable niches in the $10 \mathrm{~m}$ buried area, which are more vulnerable to environmental conditions than abundant taxa. Therefore, rare taxa may be responsive more sensitively to other environmental conditions than other rich taxa.

From the above research results, it can be seen that the geographical location is the most important factor affecting the microbial diversity and structure, whether it is a rich or rare community in the fairy peach artificial wetland. Rare groups are more sensitive to geographical location (possibly including other environmental conditions) than their abundant species.

\section{Acknowledgements}

This research was supported by grants from the National Natural Science Foundation of China (Grant No. 41371464), Supported by the study abroad fund of Yangtze University.

We are very grateful to Professor He Ji Zheng of the Chinese Academy of Sciences, the center for ecological environment research.

\section{References}

Babatunde, A.O., Zhao, Y.Q., O’Neill, M. and O'Sullivan B. 2008. Constructed wetlands for environmental pollution control: a review of developments, research and practice in Ireland. Environ. Int. 34, 116-126.

Fu, R.B., Yang, H.Z., Gu, G.W. and Zhang, Z. 2005. Analysis of substrate microorganisms status in constructed wetIands and their correlation with pollutants removal for wastewater treatment. Res. Environ. Sci. 18, 44-49. 
Fu, X.H., Liu, G.N., He, J.L., Ma, Y.Q., Song, X.K., Meng, L. and Jia, Q.M. 2017. Analysis of microbial community diversity in the Bohai Sea marine protected areas of the Shandong Province. Mar. Sci. 41, 39-47.

Fukada, T., Hiscock, K.M., Dennis, P.F. and Grischek, T. 2003. A dual isotope approach to identify denitrification in groundwater at a river-bank infiltration site. Water. Res. 37, 3070-3078.

Guo, C. 2010. Thesis. Nanjing Agricultural University, Jiangsu, Nanjing, China.

Iasur-Kruh, L., Hadar, Y., Milstein, D., Gasith, A. and Minz, D. 2010. Microbial population and activity in wetland microcosms constructed for improving treated municipal wastewater. Microb. Ecol. 59, 700-709.

Kobayashi, T., Ryder, D.S., Gordon, G., Shannon, I., Ingleton, T., Carpenter, M. and Jacobs, S.J. 2009. Short-term response of nutrients, carbon and planktonic microbial communities to floodplain wetland inundation. Aquat. Ecol. 43, 843-858.

Lance, J.C., Rice, R.C. and Gilbert, R.G. 1980. Renovation of wastewater by soil columns flooded with Primary effluent. Water. Pollut. Control. Federation. 52, 381-388.

Liang, W., Wu, Z.B., Cheng, S.P., Zhou, Q.H. and Hu, H.Y. 2003. Roles of substrate microorganisms and urease activities in wastewater purification in a constructed wetland system. Ecol. Eng. 21, 191-195.

Liu, L.L. 2014. Thesis. Xi'an University of Architecture and Technology, Shanxi, Xi'an, China.

Peralta, A.L., Matthews, J.W., Flanagan, D.N. and Kent, A.D. 2012. Environmental factors at dissimilar spatial scales influence plant and microbial communities in restored wetlands. Wetlands. 32, 1125-1134.

Qiu, Jane. 2010. China faces up to groundwater crisis. Nature. 466, 308-308.

Sánchez-Carrillo, S., Reddy, K.R., Inglett, K.S. Álvarez-Cobelas, M. and Sánchez-Andrés R. 2014. Biogeochemical indicators of nutrient enrichments in 
wetlands: the microbial response as a sensitive indicator of wetland eutrophication, $\mathrm{pp}$. 203-222. Abid A. Ansari, Eutrophication: Causes, Consequences and Control-2014, Springer Science+Business Media Dordrecht, Netherlands, Germany.

Schellekens J. 2000. The interception and runoff generating processes in the bisle catchment,luquillo experimental forest, Puerto Rico. Phys. Chem. Earth. Part. B. Hydrol. Oceans. Atmos. 25, 659-664.

Sleytr, K., Tietz, A., Langergraber. G., Haberl, R. and Sessitsch, A. 2009. Diversity of abundant bacteria in subsurface vertical flow constructed wetlands. Ecol. Eng. 35, 1021-1025.

Song, S.F., Yang, F., Ma,L.A. and Gao, X.F. 2018. Effects of sewage treatment on microbial community structure of surface water in Xiantao wetland. OALib. 5, e4583.

Vidal, J.P. and Wade, S.D. 2008. Multimodel projections of catchment-scale precipitation regime. J. Hydrol. 353, 143-158.

Willhelm, S.R., Schiff, S.L. and Robertson, W.D. 1996. Biochemical evolution of domestic waste water in septic systems: 2.Application of conceptual model in sandy aquifers. Ground. Water. 34, 853-864.

Xu, Z.Z. 2012. Thesis. Shanghai Jiao Tong University, Shanghai, Shanghai, China.

Yang, J,. Ma, L.A., Jiang, H.C., Wu, G. and Dong, H. 2016. Salinity shapes microbial diversity and community structure in surface sediments of the Qinghai-Tibetan Lakes. Sci. Rep. 6, 25078.

Yimer, F., Messing, I., Ledin, S. and Abdelkadir, A. 2008. Effects of different land use types on infiltration capacity in a catchment in the highlands of Ethiopia. Soil. Use. Manage. 24, 344-349.

Yin, J., Wen, Y. and Zhou, Q. 2007. Progress of microbial ecology in constructed wetlands. Environ. Sci. Technol. 30, 108-110.

Zhang, Y.Q., Chiew, F.H.S., Zhang, L., Leuning, R. and Cleugh, H.A. 2008. Estimating catchment evaporation and runoff using MODIS leaf area index and the 
Penman-Monteith Equation. Water. Resour. Res. 44, 2183-2188.

294 Zhou, Q.H., He, F., Zhang, L.P., Wang, Y.F. and Wu, Z.B. 2009. Characteristics of

295 the microbial communities in the integrated vertical-flow constructed wetlands. $J$.

296 Environ. Sci. 21, 1261-1267.

297

298

299

300

301

302

303

304

305

306

307

308

309

310 


\section{Table legends}

318 Table 1. Detection results of surface water and groundwater in Constructed Wetland.

\begin{tabular}{|c|c|c|c|c|c|c|}
\hline Sample & & ation & $\mathrm{COD}_{\mathrm{Cr}}(\mathrm{mg} / \mathrm{L}) \mathrm{TP}$ & $(\mathrm{mg} / \mathrm{L})$ & $\begin{array}{c}\mathrm{NH}^{+}{ }^{+}-\mathrm{N} \\
(\mathrm{mg} / \mathrm{L})\end{array}$ & $\mathrm{TN}(\mathrm{mg} / \mathrm{L})$ \\
\hline $\mathrm{MC} 1$ & -2000 & surface water & 38.59 & 0.04 & 1.96 & 2.03 \\
\hline $\mathrm{MC} 2$ & -2000 & deep of $5 \mathrm{~m}$ & 2.89 & 0.03 & 1.73 & 1.28 \\
\hline MC3 & -2000 & deep of $10 \mathrm{~m}$ & 2.37 & 0.02 & 0.49 & 1.13 \\
\hline M1 & $400 \mathrm{~m}$ & surface water & 182.53 & 5.14 & 8.81 & 19.17 \\
\hline M2 & $400 \mathrm{~m}$ & deep of $5 \mathrm{~m}$ & 3.67 & 0.18 & 1.85 & 2.94 \\
\hline M3 & $400 \mathrm{~m}$ & deep of $10 \mathrm{~m}$ & 3.00 & 0.05 & 1.14 & 1.93 \\
\hline M4 & $600 \mathrm{~m}$ & surface water & 151.66 & 4.98 & 8.43 & 16.51 \\
\hline M5 & $600 \mathrm{~m}$ & deep of $5 \mathrm{~m}$ & 2.94 & 0.05 & 1.33 & 2.87 \\
\hline M6 & $600 \mathrm{~m}$ & deep of $10 \mathrm{~m}$ & 2.36 & 0.04 & 1.08 & 1.66 \\
\hline M7 & $3000 \mathrm{~m}$ & surface water & 111.16 & 3.45 & 6.55 & 14.21 \\
\hline M8 & $3000 \mathrm{~m}$ & deep of $5 \mathrm{~m}$ & 2.92 & 0.04 & 0.96 & 1.77 \\
\hline M9 & $3000 \mathrm{~m}$ & deep of $10 \mathrm{~m}$ & 2.25 & 0.03 & 0.91 & 1.39 \\
\hline
\end{tabular}


336 Table 2. Alpha-diversity of the surface water and groundwater in the studied Xiantao

337 constructed wetland.

\begin{tabular}{cccccccc}
\hline sample & $\begin{array}{c}\text { Total } \\
\text { reads }\end{array}$ & $\begin{array}{c}\text { Observed } \\
\text { OTUs }\end{array}$ & Simpson & $\begin{array}{c}\text { Shannon_ } \\
\text { Wiener }\end{array}$ & $\begin{array}{c}\text { PD_whole } \\
\text { tree }\end{array}$ & $\begin{array}{c}\text { Good's } \\
\text { Coverage }\end{array}$ & Chao1 \\
\hline MC1 & 18976 & 802.6 & 0.994 & 8.7 & 53.5 & 0.7 & 2393.2 \\
MC2 & 21167 & 735.1 & 0.972 & 7.8 & 50.9 & 0.7 & 2306.8 \\
MC3 & 16403 & 763.7 & 0.99 & 8.2 & 57.0 & 0.7 & 2336.8 \\
M1 & 8237 & 966.7 & 0.987 & 8.7 & 59.3 & 0.6 & 3055.5 \\
M2 & 11825 & 1077.1 & 0.992 & 9.2 & 68.5 & 0.6 & 3165.8 \\
M3 & 7857 & 1046.8 & 0.991 & 9.0 & 66.6 & 0.6 & 3291.9 \\
M4 & 11839 & 937 & 0.989 & 8.7 & 60.8 & 0.6 & 2638.8 \\
\hline
\end{tabular}


bioRxiv preprint doi: https://doi.org/101101/316802; this version posted May 9, 2018. The copyright holder for this preprint (which was not certified by peer review) is the author/funder, who has granted bioRxiv a license to display the preprint in perpetuity. It is made available under aCC-BY-ND 4.0 International license.

\begin{tabular}{|c|c|c|c|c|c|c|c|}
\hline M5 & 20513 & 897 & 0.993 & 8.8 & 55.3 & 0.6 & 3029.1 \\
\hline M6 & 7066 & 848.2 & 0.98 & 8.2 & 55.2 & 0.6 & 2898.5 \\
\hline M7 & 24785 & 730.8 & 0.975 & 7.6 & 57.6 & 0.7 & 2535.6 \\
\hline M8 & 7030 & 730.4 & 0.977 & 7.7 & 51.7 & 0.7 & 2419.5 \\
\hline M9 & 5755 & 726.9 & 0.985 & 8.0 & 48.1 & 0.7 & 2243.8 \\
\hline
\end{tabular}

\section{8}


Table 3. Abundance estimates of the abundant and rare OTUs in the studied surface water and groundwater samples in this study.

\begin{tabular}{|c|c|c|c|c|}
\hline Sample & $\begin{array}{c}\text { Abundant OTUs } \\
\text { (Percentage of } \\
\text { abundant OTUs/ total OTUs } \\
\text { in each sample) }\end{array}$ & $\begin{array}{l}\text { Abundant OTU } \\
\text { relative abundance }(\%)\end{array}$ & $\begin{array}{c}\text { Rare OTUs } \\
\text { (Percentage of } \\
\text { rare OTUs/ total OTUs } \\
\text { in each sample) }\end{array}$ & $\begin{array}{l}\text { Rare } \mathrm{O}^{-} \\
\text {relative abund }\end{array}$ \\
\hline MC1 & $20(10.05 \%)$ & 67.96 & $92(46.23 \%)$ & 5.27 \\
\hline MC2 & $17(7.91 \%)$ & 77.93 & $138(64.19 \%)$ & 6.98 \\
\hline MC3 & $16(9.58 \%)$ & 79.76 & $96(57.49 \%)$ & 5.75 \\
\hline M1 & $15(10.42 \%)$ & 64.79 & $0(0.00 \%)$ & 0 \\
\hline M2 & $8(5.63 \%)$ & 66.82 & $36(25.35 \%)$ & 3.27 \\
\hline M3 & $9(7.69 \%)$ & 71.97 & $0(0 \%)$ & 0 \\
\hline M4 & $17(9.29 \%)$ & 64.66 & $37(20.22 \%)$ & 2.47 \\
\hline M5 & $12(6.45 \%)$ & 73.03 & $93(50.00 \%)$ & 5.03 \\
\hline M6 & $13(11.11 \%)$ & 74.34 & $0(0.00 \%)$ & 0 \\
\hline M7 & $14(6.01 \%)$ & 74.05 & $139(59.66 \%)$ & 6.49 \\
\hline M8 & $12(12.37 \%)$ & 80.85 & $0(0.00 \%)$ & 0 \\
\hline M9 & $15(15.15 \%)$ & 78.77 & $0(0.00 \%)$ & 0 \\
\hline
\end{tabular}


376 Table 4. Relative abundance of abundant OTUs within different phyla across the studied

377 samples in this study.

\begin{tabular}{|c|c|c|c|c|c|c|c|c|}
\hline Phylum & $\begin{array}{l}\text { Proteobacte } \\
\text { ria }\end{array}$ & $\begin{array}{l}\text { Bacteroidet } \\
\text { es }\end{array}$ & $\begin{array}{l}\text { Actinobacte } \\
\text { ria }\end{array}$ & $\begin{array}{l}\text { Cyanobacte } \\
\text { ria }\end{array}$ & Firmicutes & $\begin{array}{l}\text { Verrucomic } \\
\text { robia }\end{array}$ & Chloroflexi & $\begin{array}{l}\text { Euryarchae } \\
\text { ota }\end{array}$ \\
\hline MC1 & 29.61 & 5.95 & 19.71 & 5.95 & 1.06 & 4.61 & 1.06 & 0.00 \\
\hline MC2 & 63.30 & 14.64 & 0.00 & 0.00 & 0.00 & 0.00 & 0.00 & 0.00 \\
\hline MC3 & 72.66 & 2.15 & 0.00 & 0.00 & 1.29 & 0.00 & 3.66 & 0.00 \\
\hline M1 & 58.21 & 5.05 & 0.00 & 0.00 & 1.53 & 0.00 & 0.00 & 0.00 \\
\hline M2 & 65.37 & 0.00 & 0.00 & 0.00 & 1.45 & 0.00 & 0.00 & 0.00 \\
\hline M3 & 69.71 & 0.00 & 0.00 & 0.00 & 1.16 & 0.00 & 0.00 & 1.10 \\
\hline M4 & 54.80 & 8.39 & 0.00 & 0.00 & 1.47 & 0.00 & 0.00 & 0.00 \\
\hline
\end{tabular}


bioRxiv preprint doi: https://doi.org/10.1101/316802; this version posted May 9, 2018. The copyright holder for this preprint (which was not certified by peer review) is the author/funder, who has granted bioRxiv a license to display the preprint in perpetuity. It is made available under aCC-BY-ND 4.0 International license.

\begin{tabular}{|c|c|c|c|c|c|c|c|c|}
\hline M5 & 63.21 & 8.76 & 0.00 & 0.00 & 1.06 & 0.00 & 0.00 & 0.00 \\
\hline M6 & 66.31 & 0.00 & 0.00 & 0.00 & 8.03 & 0.00 & 0.00 & 0.00 \\
\hline M7 & 66.40 & 6.14 & 0.00 & 0.00 & 1.52 & 0.00 & 0.00 & 0.00 \\
\hline M8 & 68.14 & 0.00 & 0.00 & 11.18 & 1.53 & 0.00 & 0.00 & 0.00 \\
\hline M9 & 40.24 & 38.53 & 0.00 & 0.00 & 0.00 & 0.00 & 0.00 & 0.00 \\
\hline
\end{tabular}

\section{8}

380

381

382

383

384

385

386

387

388

389

390

391

392

393

394 
Table 5. Relative abundance $(\%)$ of top 10 classes in the surface water and groundwater of

the studied Xiantao constructed wetland.

\begin{tabular}{|c|c|c|c|c|c|c|c|c|}
\hline Top10 classes & $\begin{array}{l}\text { Betaproteob } \\
\text { acteria }\end{array}$ & Bacilli & $\begin{array}{l}\text { Gammaprote } \\
\text { obacteria }\end{array}$ & $\begin{array}{l}\text { Alphaproteo } \\
\text { bacteria }\end{array}$ & $\begin{array}{l}\text { Flavobacteri } \\
\text { ia }\end{array}$ & $\begin{array}{l}\text { Epsilonprote } \\
\text { obacteria }\end{array}$ & Bacteroidia & $\begin{array}{l}\text { Melainab } \\
\text { eria }\end{array}$ \\
\hline MC1 & 32.58 & 3.16 & 2.66 & 5.95 & 5.17 & 0.11 & 0.13 & 0.13 \\
\hline MC2 & 60.24 & 1.24 & 7.68 & 1.42 & 0.56 & 0.13 & 13.16 & 0.04 \\
\hline MC3 & 44.14 & 3.53 & 34.38 & 1.91 & 0.51 & 0.09 & 3.46 & 0.00 \\
\hline M1 & 60.19 & 2.56 & 9.71 & 2.78 & 6.25 & 4.94 & 2.67 & 0.00 \\
\hline M2 & 74.35 & 1.95 & 4.54 & 2.72 & 0.86 & 0.32 & 0.00 & 0.23 \\
\hline M3 & 76.05 & 2.48 & 5.67 & 2.04 & 0.83 & 0.33 & 0.77 & 0.50 \\
\hline M4 & 54.30 & 2.41 & 10.33 & 2.54 & 7.99 & 6.02 & 4.95 & 0.07 \\
\hline M5 & 36.31 & 2.55 & 37.74 & 1.90 & 0.65 & 0.09 & 0.75 & 0.95 \\
\hline M6 & 27.25 & 11.42 & 12.55 & 37.70 & 1.64 & 0.34 & 0.79 & 0.23 \\
\hline M7 & 57.47 & 1.17 & 3.56 & 1.59 & 5.70 & 15.50 & 3.85 & 0.05 \\
\hline M8 & 59.76 & 3.22 & 13.55 & 4.59 & 0.21 & 0.21 & 0.00 & 11.18 \\
\hline M9 & 36.13 & 0.63 & 10.23 & 2.34 & 31.65 & 0.19 & 2.21 & 0.00 \\
\hline
\end{tabular}


415 Table 6. Mantel test showing the correlation between structure of community similarity and environment parameters of the studied surface water and groundwater in this study.

\begin{tabular}{ccc}
\hline & Abundant OTUs & All OTUs \\
\hline COD & $0.520^{* *}$ & $0.530^{* *}$ \\
$\mathrm{TP}$ & 0.206 & 0.232 \\
$\mathrm{NH} 4_{+}-\mathrm{N}$ & $0.325^{*}$ & $0.337^{*}$ \\
$\mathrm{TN}$ & $0.304^{*}$ & $0.325^{*}$
\end{tabular}


444 Figure 1. Bray-Curtis similarity-based cluster analysis (left) of structure of community in the studied 
bioRxiv preprint doi: https://doi org/10 1101/316802- this version posted May 9,2018 . The copyright holder for this preprint (which was not certified by peer review) is the author/funder, who has granted bioRxiv a license to display the preprint in perpetuity. It is made available under aCC-BY-ND 4.0 International license.

445 samples and schematic figures (right) showing the frequencies of OTUs affiliated with major phyla in this study.

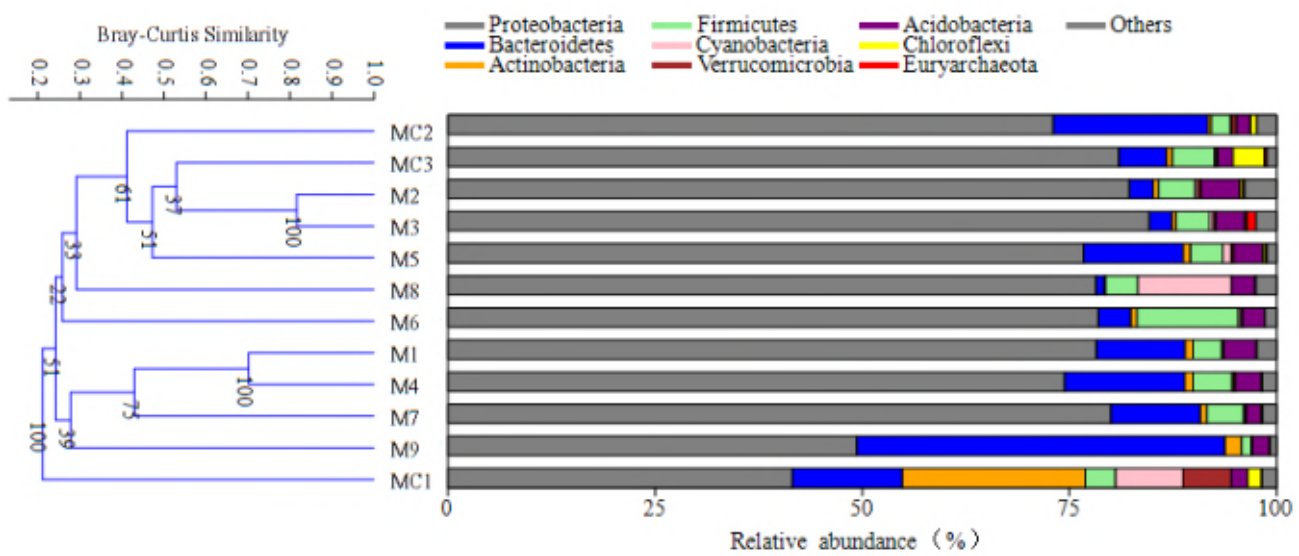


474 Figure 2. Clustering and principal coordinates analysis of total MCC among the studied samples based on
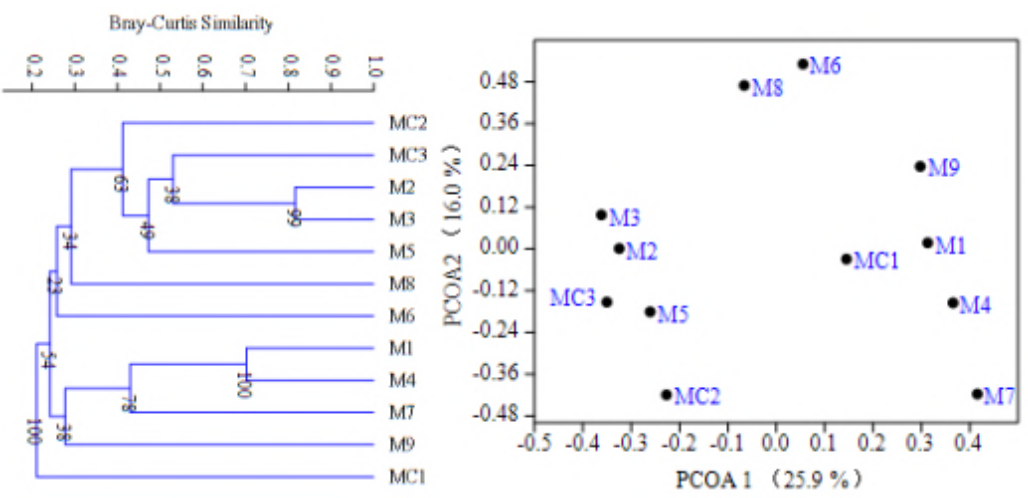
506 Figure 3. Cluster analyses and principal coordinates analyses of abundant structure of community among the studied samples based on Bray-Curtis similarity.

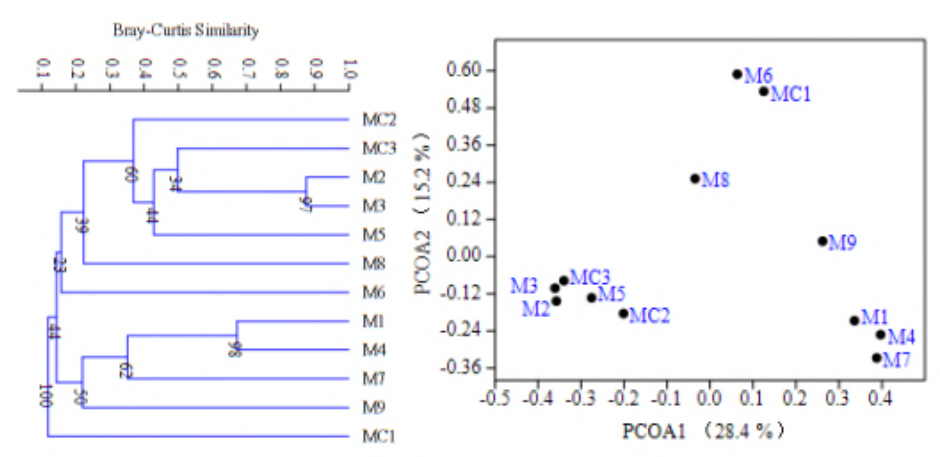

Abundant Subcommunity 